\title{
The Genetic Sonogram-Structural Anomalies in the Assessment of Trisomy 21: Case Reports and a Literature Review
}

\author{
Yaron Zalel
}

\begin{abstract}
The detection of sonographic markers can modify the risk of fetal Down syndrome (DS) and is the basis of the so-called genetic sonogram.

We present herein our experience with five cases found during early anomaly scan. They all share a common pathologyDS, but each has a different sonographic appearance with unique structural abnormalities. The detailed cases are desrcibed along with literature review of the sonographic findings. Using the 'soft' markers alone as a basis of deciding to offer amniocentesis will result in more fetal losses than DS detected. Therefore, the use of the genetic sonogram, especially in early pregnancy, based mainly on structural anomalies, will lessen the false-positive DS detection.
\end{abstract}

Keywords: Genetic sonogram, Down syndrome, Structural abnormalities, Early pregnancy, Ultrasonography.

How to cite this article: Zalel Y. The Genetic SonogramStructural Anomalies in the Assessment of Trisomy 21: Case Reports and a Literature Review. Donald School J Ultrasound Obstet G ynecol 2013;7(4):475-480.

\section{Source of support $\mathrm{Nil}$}

Conflict of interest: None declared

\section{INTRODUCTION}

Nyberg et al $^{1}$ have stated that the presence or absence of sonographic markers can substantially modify the risk of fetal Down syndrome (DS) and is the basis of the so-called genetic sonogram. Fetuses that have structural anomalies often have chromosomal abnormalities. Between 10 and $37 \%$ of fetuses with structural anomalies also have chromosomal defects. Half of these have trisomies, a quarter monosomy, 10 to $15 \%$ a mosaic and a few triploidy and miscellaneous aneuploidies. ${ }^{2,3}$

Nicolaides et al ${ }^{4}$ have show $n$ that fetuses that have more than one anomaly are more likely to have chromosomal anomalies. With one anomaly, the risk of chromosomal abnormality is $2 \%$, it rises to $11 \%$ with two anomalies, to $66 \%$ with five and up to $92 \%$ with eight anomalies. K rantz et $a^{5}$ have evaluated both the genetic sonogram as well as biochemical screening. First trimester combined screening al one resulted in a detection rate of $88.5 \%$ with a $4.2 \%$ falsepositive rate. The genetic sonogram included nuchal fold, hyperechogenic bow el, short femur and humerus, echogenic intracardiac foci (ECF), pyelectasis and major abnormality. The sonographic examination (with one marker found) detected an additional $8 \%$ of DS with false-positive rate of $13.2 \%$. The overall detection rate was $94.6 \%$ and falsepositive rate of $5.4 \%$. They concluded that second trimester genetic sonogram, if used properly, can be an effective sequential screening following first trimester DS biochemical screening.

In another study, detecting chromosomal abnormalities by second-trimester genetic sonogram in a community-based antenatal testing unit, Bottalico et $\mathrm{al}^{6}$ had $4.85 \%$ chromosomal abnormalities. DS occurred in $3.75 \%$, of which $66.6 \%$ had a positive ultrasound examination in the second trimester. Six of seven $(85.7 \%)$ of the trisomy 18 fetuses, $2 / 2$ of trisomy 13 and $2 / 3$ of the nonmosaic $45, X$ fetuses had positive sonograms. The overall detection rate for chromosomal abnormalities was 20/32 with a sensitivity $62.5 \%$, specificity $80.7 \%$, negative predictive value $97.7 \%$, positive predictive value $14.2 \%$ and positive likelihood ratio (LR) 3.24.

Nyberg et $\mathrm{al}^{7}$ have evaluated the yield of isolated sonographic marker for detection of fetal DS in the second trimester of pregnancy. $M$ ajor structural abnormalities were observed in $16.7 \%$ with trisomy 21 and in $0.6 \%$ of the control group ( $p<0.001)$. M ajor abnormality, minor marker or both, occurred in $68.8 \%$ of fetuses with trisomy 21 compared with $13.6 \%$ of the control fetuses $(p<0.001)$. A n isolated minor or 'soft' marker was the only sonographic finding in $22.6 \%$ fetuses with trisomy 21 compared with $11.3 \%$ of the control group $(p<0.001)$. Nuchal thickening (LR: 11) and hyperechogenic bowel (LR: 6.7) showed the strongest association with trisomy 21 as an isolated markers. The most common isolated marker was ECF in both affected $(7.1 \%)$ and control fetuses $(3.9 \%)$ but carried a low risk $(p=0.46, L R: 1.8)$.

Nyberg et al ${ }^{1}$ review ed the second trimester sonographic findings of the major trisomies $(13,18$ and 21). They have examined nuchal thickening, hyperechogenic bowel, ECF, pyelectasis, mild ventricular dilatation and choroid plexus cysts (CPC) and found that one or more sonographic findings can be identified in approximately $90 \%$ of fetuses with trisomy $13,80 \%$ with trisomy 18 and 50 to $70 \%$ of the fetuses with DS. Likewise, Zhong et al ${ }^{8}$ have found that the strongest association between sonographic markers and DS, besides nuchal fold thickness (with odd ratio of 30.9) was 
with any major abnormality with OR of 24.2. Therefore, we think that in order to avoid these FP detection rates leading to unnecessary invasive procedures, we advocate the use of the genetic sonogram, based on structural abnormalities mainly, and especially in early pregnancy.

\section{Trisomy 21-Case Reports and Literature Review}

In this review, I describe herein trisomy 21 cases, detected in early anomaly scan, with a review of the literature regarding the abnormalities found in these cases. The next five cases share a common pathology, D own syndrome, but each one has a different sonographic appearance.

The first case, age 36 years, in her $14+5$ weeks of gestation, presented with the following findings-increased nuchal fold $(4.3 \mathrm{~mm})$, absent one nasal bone and hypoplastic middle phalanx of the fifth digit (MPFD). Nuchal translucency (NT) is the sonographic appearance of a collection of fluid under the skin behind the fetal neck in the first-trimester of pregnancy. It is a sonographic examination done between $11-13+6$ weeks of gestation with the 12 week as the preferred time. In fetuses carrying chromosomal abnormalities, cardiac defects and many genetic syndromes, the amount of fluid is larger and hence, the NT thickness is increased. Nicolaides et al ${ }^{9}$ have examined the significance of fetal NT at 10 to 14 weeks' gestation in the prediction of abnormal fetal karyotype. The incidence of chromosomal defects was $3 \%$. In the $6 \%$ fetuses with NT 3 to $8 \mathrm{~mm}$ thick the incidence of chromosomal defects was $35 \%$. In contrast, only $1 \%$ of the remaining fetuses were chromosomally abnormal. In Pandya et al's study, ${ }^{10}$ the NT was above the 95 th percentile in $77 \%$ of fetuses with trisomy 21 and in $78 \%$ of those with other chromosomal defects. They proposed, on the basis of the distribution of NT measurements in normal fetuses and those with trisomy 21 , a new method of screening which involves assessment of individual risk based on the combination of fetal NT, crown-rump length and maternal age. We should remember, as in Kagan's study, ${ }^{11}$ that in fetuses with increased NT, approximately one-half of the chromosomally abnormal group is affected by defects other than trisomy. Cicero and $\mathrm{Nicolaides}{ }^{12}$ have evaluated the nasal bone for aneuploidy. The nasal bone was absent in 43/59 (73\%) trisomy 21 fetuses and in only $0.5 \%$ of the chromosomally normal fetuses, making the LR for trisomy 21-146. They ${ }^{13}$ have further studied nasal bone hypoplasia at 15 to 22 weeks' gestation and found that the nasal bone was hypoplastic in $61.8 \%$ fetuses with trisomy 21 , in $1.2 \%$ chromosomally normal fetuses and in $3.3 \%$ fetuses with other chromosomal defects. In another study, the same group ${ }^{14}$ have studied the nasal bone in screening for trisomies and found that the nasal bone was absent in $2.6 \%$ of the euploid fetuses, $59.8 \%$ with trisomy $21,52.8 \%$ with trisomy $18,45 \%$ with trisomy 13 and in none of the fetuses with Turner syndrome. It should, though, be remembered, that not all researchers have repeated the same results. Thus, $M$ alone et al ${ }^{15}$ found that first-trimester nasal bone evaluation was not a useful test for population screening for trisomy 21 and added little to first trimester NT screening. They concluded that the difficulty in performing first trimester nasal bone sonography consistently, in the general population setting, will significantly limit the usefulness of this aneuploidy screening technique. Later on, B enoit and Chaoui, ${ }^{16}$ using three-dimensional ultrasound with maximal mode rendering, found that unilateral absence or hypoplasia of nasal bone is an important and new observation in fetuses with DS, as was the finding in our case.

This case had also hypoplasia of the M PFD. A bsence or hypoplasia of the M PFD is present in $60 \%$ of neonates with DS. ${ }^{17}$ W hat is the normal sequence of ossification process of the M PFD? Radiographic post mortem studies show that the MPFD develops last of all the phalanx in the hand. Ossification takes place in the range of CRL 90 to $125 \mathrm{~mm}$ (14-16 weeks gestation). Ossification sequence of the phal anx in DS fetuses is normal but all the ossification process is abnormal with MPFD even more delayed, abnormal in shape, or absent. ${ }^{18}$ If we look at the following Table 1 with prenatal studies regarding the association of absence of the M PFD, the incidence varies between $15.4 \%,{ }^{19}$ $18.1 \%{ }^{20}$ and up to $25 \% .{ }^{21}$

Thus, hypoplasia of the middle phalanx of the fifth finger as well as reduced ratio of the middle phalanges of the fifth to the fourth digit were described among the sonographic features in fetuses with DS. However, these studies were

\begin{tabular}{lll}
\multicolumn{3}{c}{ Table 1: MPFD and Trisomy 21} \\
\hline Authors & Normal fetuses & $\begin{array}{l}\text { Trisomy } 21 \\
\text { fetuses }\end{array}$ \\
\hline Benacerraf B & $6.3 \%(65 / 1,032)$ & $25 \%(2 / 8)$ \\
$\begin{array}{l}\text { 15-20 weeks } \\
\text { J Ultrasound Med 1990 }\end{array}$ & $33 / 6515-16$ weeks & $1 / 215-16$ weeks \\
$\begin{array}{l}\text { Vintzileos AM } \\
\text { 15-23 weeks }\end{array}$ & $3.1 \%(13 / 420)$ & $15.4 \%(2 / 13)$ \\
$\begin{array}{l}\text { Obstet Gynecol } 1996 \\
\text { Hobbins J C }\end{array}$ & NA & $18.1 \%(17 / 94)$ \\
$\begin{array}{l}\text { 14-24 weeks } \\
\text { J Ultrasound Med 2003 }\end{array}$ & & \\
\hline Total & $5.2 \%(78 / 1,475)$ & $18.2 \%(21 / 115)$ \\
\hline
\end{tabular}


The Genetic Sonogram-Structural Anomalies in the Assessment of Trisomy 21: Case Reports and a Literature R eview

conducted between 15 and 20 weeks of gestation and dealt with hypoplasia rather than absence of the middle phalanx. $W \mathrm{e}^{22}$ have assessed the in utero ossification process of the MPFD, between 13 and 17 weeks of gestation. A total of 682 pregnant women with normal fetal anatomic examination and normal pregnancy outcome were examined. The rate of the MPFD visualization increased gradually from $14.2 \%$ at 13 weeks of gestation, to $70,82.2$, 97.3 and $100 \%$ at $14,15,16$ and 17 week of gestation respectively.

Benacerraf et $a^{21}$ have found that in DS fetuses, the median ratio between the MPFD over the mid phalanx of the fourth digit, was lower $(0.59)$ in comparison to normal fetuses (0.85). They stated that using an arbitrary cutoff point of 0.70 would detect $75 \%$ of the fetuses with trisomy 21. Complete absence of the M PFD was detected in $25 \%(2 / 8)$ of DS fetuses and in $6.3 \%(65 / 1,032)$ of normal fetuses. Fifty percent of the later group was between 15 and 16 weeks of gestation.

So, we $e^{22}$ concluded that nonossification or hypoplasia of the M PFD before 17 weeks of gestation, reflects a normal development of the fetal phalanges.

This emphasizes the limited role of the MPFD nonossification as a sonographic 'marker' of DS before 17 weeks of gestation (Figs $1 A$ and $B$ ).

The second case, 31 years old woman at her 14 weeks, presented with severe edema, mediastinal cystic hygroma (Fig. 2), echogenic cardiac foci (ECF), chorioamniotic separation and short long bones but with normal nuchal fold.

The next case (no. 3), 14+3 weeks in a 32 years old woman, presented with metopic wormian bone, short long bones, hypoplastic nasal bone, ECF (Fig. 3), absent M PFD and normal NT. Chaoui et al ${ }^{23}$ have described abnormal metopic suture using three-dimensional ultrasound with maximal mode rendering. They have found four types of abnormality in the metopic suture, i.e. delayed development ( $V$ or $Y$-shape), U-shaped, premature closure and the presence of additional bone. W ormian bone derives from the 1,643 description of the sutural bones by Olas W orm to Thomas Bartholin. Early in the 16th century the first association between wormian bones and cerebral disorders was recognized. The incidence is not quite known and supposed to be around $11.3 \%$ in fetuses, higher in the normal adult population (8-15\%) and up to $54 \%$ in mentally disabled. There is no difference between sexes and the commonest suture to arise is the Lambdoid suture (50\%), follow ed by the coronal suture (25\%). ${ }^{24}$ In a recent study, ${ }^{25}$ there was a high proportion (53\%) of wormian bones in the general pediatric population and in their study wormian bones in the lambdoid suture were also found by far the greatest numbers. While searching the literature, we have found only numerous cases of wormian bone associated with chromosomal abnormalities. $M$ ainly, there are some reports of skeletal dysplasia associated with various chromosomal abnormalities. The dysplasias include cleidocranial dysplasia associated with de novo balanced translocation, 26,27 pathogenic gene mutation, ${ }^{28}$ mutations in the RUNX 2 gene ${ }^{29}$ and abnormalities of $8 q 22 .{ }^{30}$ Osteogenesis imperfecta is al so associated with mutations in COL $1 \mathrm{~A} 1 / 2^{31,32}$ as well as other rare skeletal dysplasias. A nother report of the association of wormian bones and chromosomal abnormalities is Lhermitte-Duclos disease arising in the paternal chromosome and presented with polydactyly and wormian bone. $^{33}$ In Faro's study, ${ }^{34}$ the development of the frontal bones and metopic suture in trisomy 21 is as normal and independent from the development of the nasal bones. So,
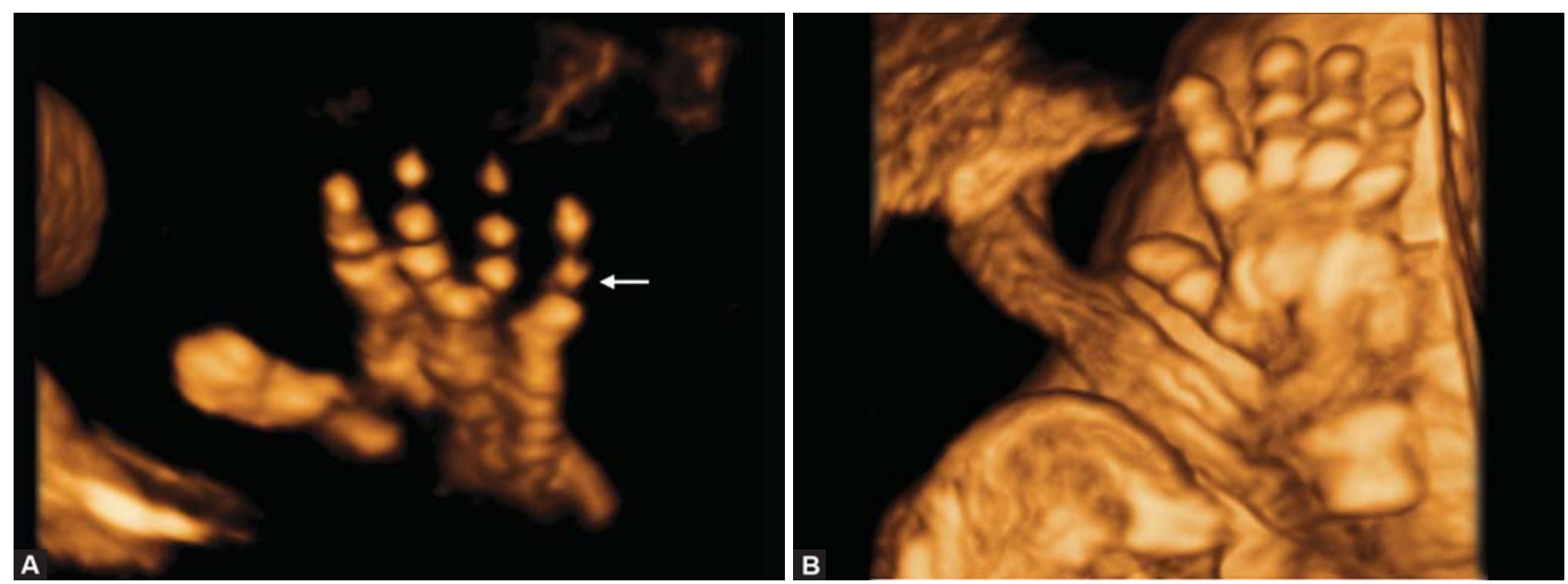

Figs 1A and B: Normal and hypoplastic MPFD (Case 1) 


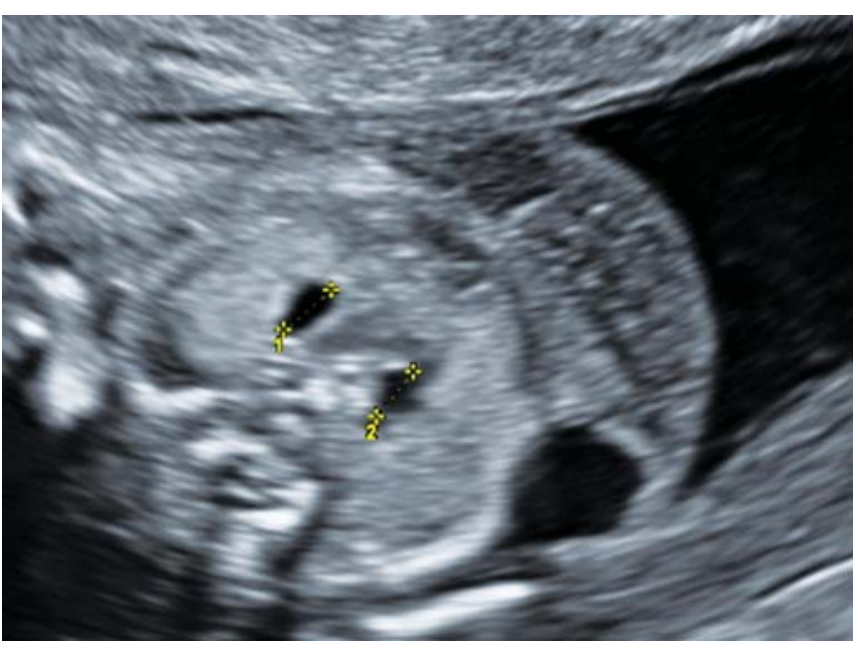

Fig. 2: Mediastinal cystic hygroma (Case 2)

our case with metopic wormian bone is the first association between wormian bone and trisomy 21 .

The next case (no. 4), aged 36 in her $15+5$ gestational week, presented with the 'classical' sighs for DS. It had atrioventricular (AV) septal defect (AV canal), increased nuchal fold, ECF, hypoplastic nasal bone, echogenic bow el (Fig. 4) and absent MPFD. AV canal is a common AV junction with a five-leaflet common valve. The incidence is 3 to $7 \%$ of congenital heart defects in infants and in fetuses the incidence is higher: 11 to $17 \%$. It has three types (A-C) according to Rastellis classification. Regarding prenatal diagnosis, the normal: A V valves have a differential insertion on the septum. The tricuspid valve is slightly more apically inserted. The view of the A V valves with the septum and septum primum provide an image with resembles a cross-the crux of the heart. The sonographic appearance of A V canal include a large hole in the middle of the heart and the absence of the crux, linear insertion (nondifferential insertion) of the AV valves, common AV junction and VSD or absence of septum primum. A total of $66 \%$ of fetuses with A V septal defect have DS and $25 \%$ of fetuses with DS have A V D. ${ }^{35-37}$

The fifth case has no structural abnormality-only vascular aberrations. The woman, aged 32 in her $15+1$ gestational week, presented with aberrant right subclavian artery (A RSA) (Fig. 5), umbilical vein (UV) anomaly along with ECF. ARSA was proposed as a new sonographic findings as a marker tool for the detection of high risk fetuses for DS, first by Chaoui et al ${ }^{38}$ and later by us. ${ }^{39} \mathrm{~B}$ oth groups had similar results-in DS fetuses the incidence of ARSA was $37.5 \%$, in comparison to normal fetuses- $1.4 \%$, making the $L R=25$ (Chaoui) and odds ratio (OR) of 42 (in our study). In our study, in all our DS cases it was found in combination with other sonographic markers and/or abnormalities, such as persistent left SV C (PLSVC), cystic

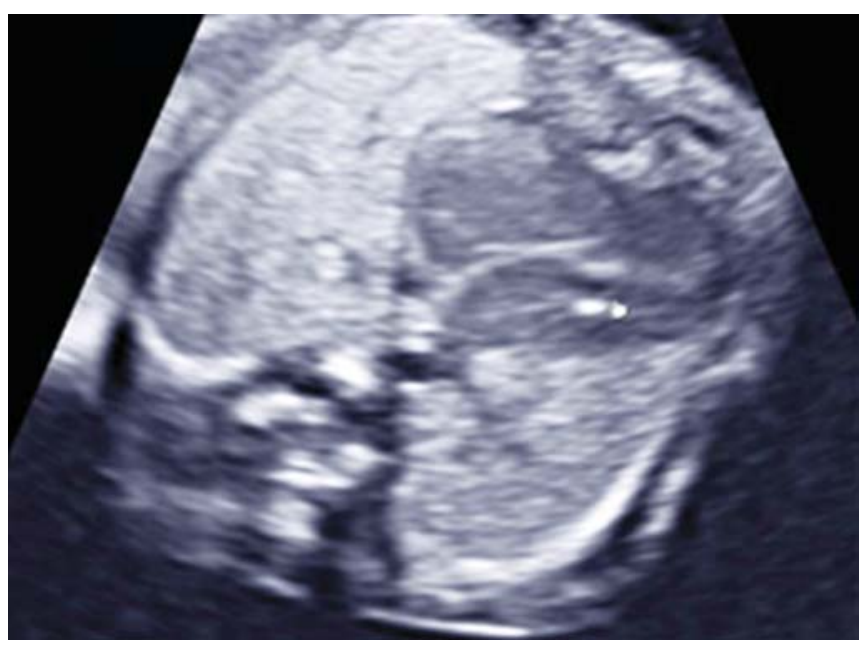

Fig. 3: Echogenic cardiac foci (Case 3)

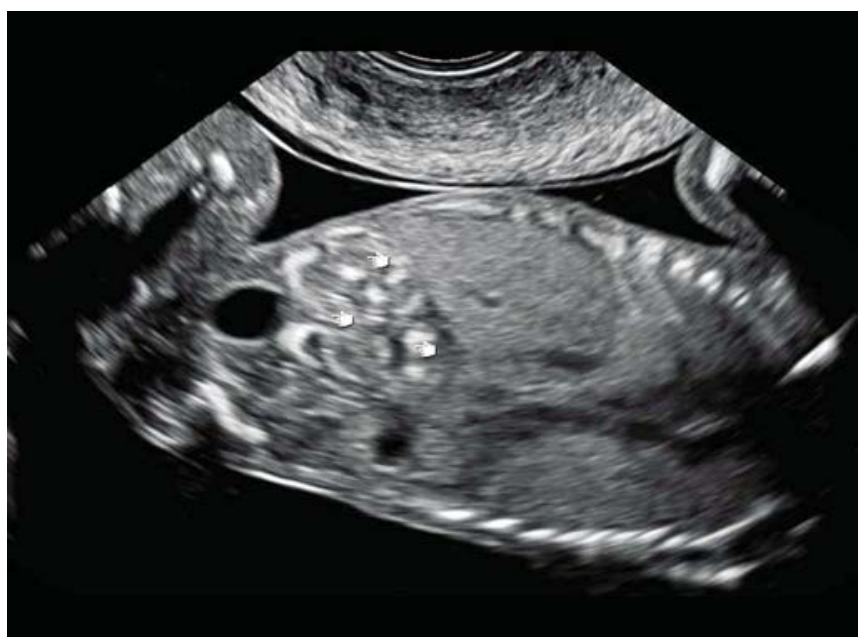

Fig. 4: Echogenic bowel (Case 4)

hygroma with tricuspid regurgitation and ECF, bilateral CPC, hyperechogenic bowel with polyhydramnios and VSD.

A chiron et al ${ }^{40}$ have found that in $11 \%$ the UV was connected to the hepatic portion of the inferior vena cava (IVC) at a position lower than its usual site while only $0.12 \%$ fetuses with normal karyotype demonstrated similar anomalous insertion of the UV into the IVC, making the OR for abnormal umbilicoportal venous system in fetuses with DS compared with the normal population of 107.4. O ur case had also the same UV anomaly.

We have to remember that DS cases do not al ways present with structural abnormalities. We have a case of a woman that we have followed in three pregnancies- the first one presented with ARSA as an isolated finding. The karyotype revealed denovotranslocation and she terminated the pregnancy. In the second pregnancy the anomaly scan reveal ed double aortic arch-the karyotype was normal. In the third pregnancy, while she was 35 years old she had a 


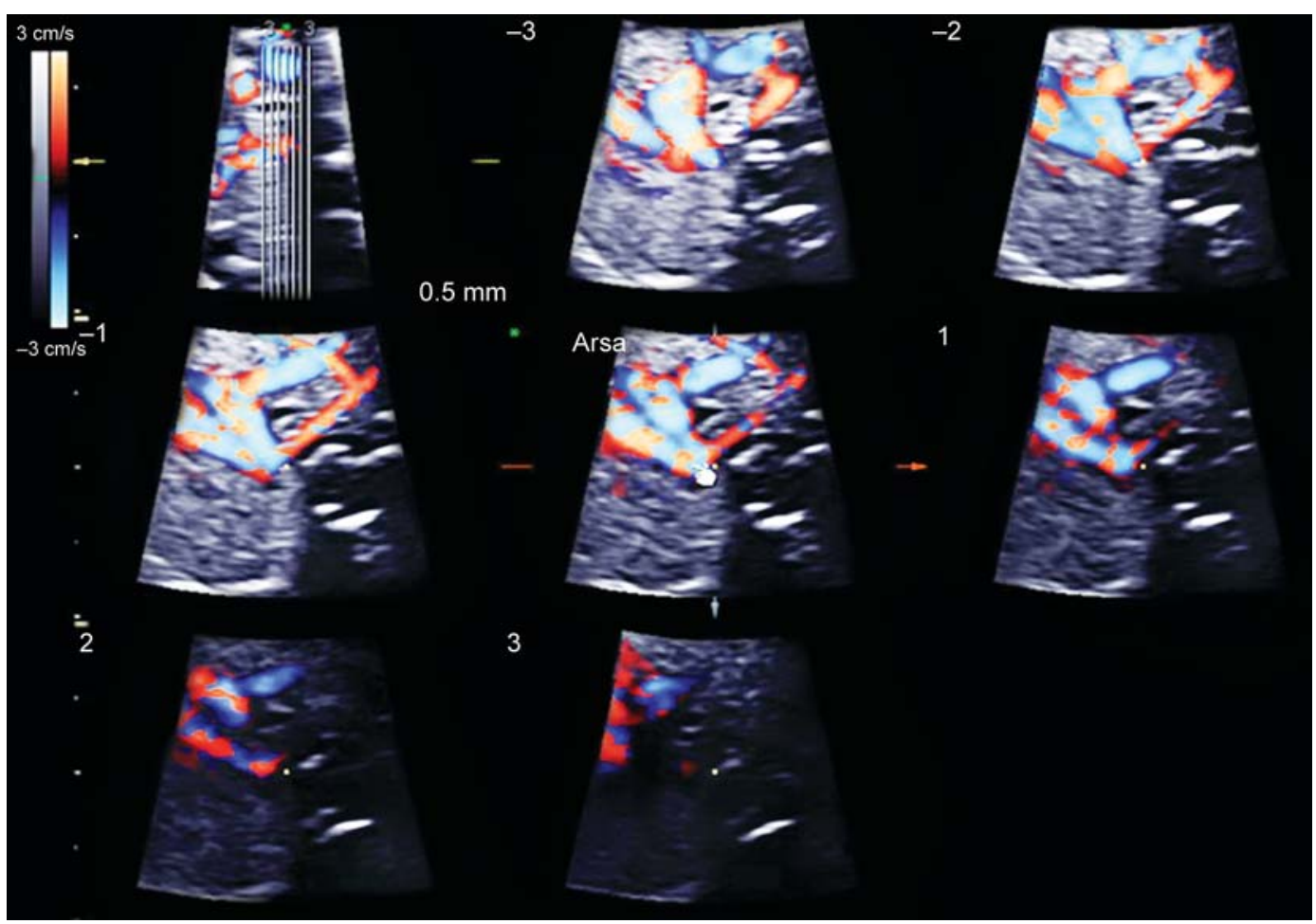

Fig. 5: ARSA (demonstrated by TUI) (Case 5)

normal NT scan at 12 weeks and anomaly scan at 15 weeks. The triple test had a 1:80 risk for DS and the karyotype was indeed DS.

\section{CONCLUSION}

W e have shown herein the various presentations of DS cases. We have described five different cases of DS, having each a unique sonographic abnormality and reviewed the literature dealing with these findings. The meta-analysis done by Smith-B indman ${ }^{41}$ searching 56 articles (1980-1999) describing 1930 DS fetuses and 130,365 normal fetuses. This meta-analysis revealed that when observed without associated structural anomalies, ultrasonographic markers could not discriminate well between unaffected fetuses and DS fetuses. U sing these markers as a basis of deciding to offer amniocentesis will result in more fetal losses than DS detected and will lead to decrease in the prenatal detection of DS.

Therefore, the use of the genetic sonogram, especially in early pregnancy, based mainly on structural anomalies, will lessen the false-positive DS detection and hence, the anxiety of the patients or terminating the pregnancy when necessary.

\section{REFERENCES}

1. Nyberg D A, Souter V L. Sonographic markers of fetal trisomies: second trimester. J UItrasound M ed 2001 J un;20(6):655-674.
2. W ladimiroff JW, Sachs ES, R euss A, Stewart PA, Pijpers L, N iermeijer M F . Prenatal diagnosis of chromosome abnormalities in the presence of fetal structural defects. A m J M ed G enet 1988 Feb;29(2):289-291.

3. Palmer CG, M iles JH, H oward-Peebles PN, M agenis RE, Patil $S$, Friedman J M. Fetal karyotype following ascertainment of fetal anomalies by ultrasound. Prenat Diagn 1987 Oct;7(8):551555.

4. Nicolaides KH, Snijders RJ, Gosden CM, Berry C, Campbell S. Ultrasonographically detectable markers of fetal chromosomal abnormalities. L ancet 1992 Sep 19;340(8821):704-707.

5. Krantz DA, Hallahan TW, M acri VJ, M acri J N. Genetic sonography after first-trimester Down syndrome screening. Ultrasound Obstet Gynecol 2007 J un;29(6):666-670.

6. B ottalico J N, Chen X, Tartaglia M, Rosario B, Y arabothu D, Nelson $L$. Second-trimester genetic sonogram for detection of fetal chromosomal abnormalities in a community-based antenatal testing unit. Ultrasound Obstet Gynecol 2009 Feb;33(2): 161-168.

7. Nyberg DA, Souter V L, El-B astawissi A, Y oung S, L uthhardt $F$, L uthy DA . I solated sonographic markers for detection of fetal Down syndrome in the second trimester of pregnancy. Ultrasound M ed 2001 Oct;20(10):1053-1063.

8. Zhong $Y$, Longman $R, B$ radshaw $R$, Odibo A O. The genetic sonogram: comparing the use of likel ihood ratios versus logistic regression coefficients for Down syndrome screening. J Ultrasound M ed 2011 A pr;30(4):463-469.

9. Nicolaides KH, A zar G, Byrne D, M ansur C, M arks K. Fetal nuchal translucency: ultrasound screening for chromosomal defects in first trimester of pregnancy. BMJ 1992 A pr;304(6831):867-869.

10. Pandya PP, Snijders RJ, J ohnson SP, De Lourdes B rizot M, $\mathrm{Nicolaides} \mathrm{KH}$. Screening for fetal trisomies by maternal age 
and fetal nuchal translucency thickness at 10 to 14 weeks of gestation. Br J Obstet Gynaecol 1995 Dec;102(12):957-962.

11. Kagan KO, Avgidou K, M olina FS, Gajewska K, Nicolaides $\mathrm{KH}$. Relation between increased fetal nuchal translucency thickness and chromosomal defects. Obstet Gynecol 2006 Jan;107(1):6-10.

12. Cicero S, Curcio P, Papageorghiou A, Sonek J, Nicolaides K. A bsence of nasal bone in fetuses with trisomy 21 at 11-14 weeks of gestation: an observational study. Lancet 2001 Nov;358(9294):1665-1667.

13. Cicero S, Sonek JD, M CK enna DS, Croom CS, Johnson L, Nicolaides K H. Nasal bone hypoplasia in trisomy 21 at 15-22 weeks' gestation. Ultrasound O bstet Gynecol 2003 J an;21(1): 15-18.

14. Kagan $\mathrm{K} \mathrm{O}$, Cicero S, Staboulidou I, W right D, N icolaides K H. Fetal nasal bone in screening for trisomies 21, 18 and 13 and Turner syndrome at 11-13 weeks of gestation. U Itrasound O bstet Gynecol. 2009 M ar;33(3):259-264.

15. Malone FD, Ball RH, Nyberg DA, Comstock CH, Saade G, Berkowitz RL, Dugoff L, Craigo SD, Carr SR, W olfe HM , Tripp $T$, D'A Iton M E; Faster research consortium. First-trimester nasal bone eval uation for aneuploidy in the general population. 0 bstet Gynecol 2004 Dec;104(6):1222-1228.

16. B enoit B, Chaoui R. Three-dimensional ultrasound with maximal mode rendering: a novel technique for the diagnosis of bilateral or unilateral absence or hypoplasia of nasal bones in secondtrimester screening for Down syndrome. Ultrasound Obstet Gynecol 2005 J an;25(1):19-24.

17. Jones KL. Smith's recognizable patterns of human malformations. 5th ed. Philadelphia, PA: W B Saunders Co; 1997. p 8-13.

18. K jaer M S, K eeling J W, A ndersen E, F ischer Hansen B, K jaer I. Hand development in trisomy 21. A m J M ed Genet 1998 Oct 12;79(5):337-342.

19. Vintzileos A M , Campbell WA, Rodis JF, Guzman ER, Smulian $J C, K$ nuppel $R A$. The use of second-trimester genetic sonogram in guiding clinical management of patients at increased risk for fetal trisomy 21. Obstet Gynecol 1996 J un;87(6):948-952.

20. Hobbins J C, L ezotte DC, Persutte W H, D eV ore GR, B enacerraf $B R$, Nyberg DA, V intzileos A M , Platt L D , C arlson DE, B ahadoSingh RO, et al. A n 8-center study to evaluate the utility of mid-term genetic sonograms among high-risk pregnancies. J Ultrasound M ed 2003 J an;22(1):33-38.

21. Benacerraf BR, Harlow BL, Frigoletto FD Jr. Hypoplasia of the middle phalanx of the fifth digit. A feature of the second trimester fetus with Down's syndrome. J U Itrasound M ed 1990 Jul;9(7):389-394

22. Zalel $Y, A$ chiron $R, K$ ivilevich $Z$. Sonographic visualization of the middle phalanx of the fetal fifth digit between 13 and 17 weeks of gestation. UItrasound Obstet Gynecol 2007 Sep;30(3):263-265.

23. Chaoui R, Levaillant JM, B enoit B, Faro C, Wegrzyn P, Nicolaides KH. Three-dimensional sonographic description of abnormal metopic suture in second- and third-trimester fetuses. Ultrasound Obstet Gynecol 2005 Dec;26(7):761-764.

24. Jeanty P, Silva SR, Turner C. Prenatal diagnosis of wormian bones. J Ultrasound M ed 2000 Dec;19(12):863-869.

25. $M$ arti B, Sirinelli D, M aurin L, Carpentier E. W ormian bones in a general paediatric population. Diagn Interv Imaging 2013 A pr;94(4):428-432.

26. Winer $N$, L e Caignec $C$, Quere M P, David A, Boceno M, A ubron F, J oubert M, Boog G, Philippe HJ, Rival J M. Prenatal diagnosis of a cleidocranial dysplasia-like phenotype associated with a de novo balanced $t(2 q ; 6 q)(q 36 ; q 16)$ translocation. UItrasound Obstet Gynecol 2003 Dec;22(6):648-651.

27. Purandare $S M, M$ endoza-L ondono $R, Y$ atsenko $S A, N$ apierala D, Scott DA, Sibai T, Casas K, Wilson P, Lee J, M uneer R, et al. De novo three-way chromosome translocation $46, X Y, t(4 ; 6 ; 21)(p 16 ; p 21.1 ; q 21)$ in a male with cleidocranial dysplasia. A m J M ed Genet A 2008 Feb;146A (4):453-458.

28. Wang $G X, M a L X, X u W F$, Song $F L$, Sun RP. Clinical and image features, and identification of pathogenic gene mutation of two cleidocranial dysplasia families. Zhonghua Er KeZaZhi 2010 N ov;48(11):834-838.

29. Otto $F, K$ anegane $H, M$ undlos $S$. M utations in the RUNX 2 gene in patients with cleidocranial dysplasia. Hum Mutat 2002 $M$ ar;19(3):209-216.

30. B rueton LA, Reeve A, Ellis $R$, Husband $P$, Thompson EM, Kingston $\mathrm{HM}$. A pparent cleidocranial dysplasia associated with abnormalities of $8 \mathrm{q} 22$ in three individuals. A m J M ed Genet 1992 J un;43(3):612-618.

31. Semler $\mathrm{O}, \mathrm{C}$ heung M S, Glorieux FH, Rauch F. W ormian bones in osteogenesis imperfecta: Correlation to clinical findings and genotype. A m J Med Genet A 2010 Jul;152A (7):1681-1687.

32. Steiner RD, Adsit J, Basel D. COL 1A 1/2-related osteogenesis imperfecta. In: Pagon RA, A dam M P, Bird TD, Dolan CR, Fong CT, Stephens K, editors. GeneR eviews ${ }^{T M}$ [Internet]. Seattle (WA ): University of W ashington, Seattle; 1993-2013. 2005 J an 28.

33. Delatycki MB, Danks A, Churchyard A, Zhou XP, Eng C. De novo germ line PTEN mutation in a man with $L$ hermitte-Duclos disease which arose on the paternal chromosome and was transmitted to his child with polydactyly and W ormian bones. J M ed Genet 2003 A ug;40(8):e92.

34. Faro C, W egrzyn $P, B$ enoit B, C haoui R, Nicolaides K. M etopic suture in fetuses with trisomy 21 at $11+0$ to $13+6$ weeks of gestation. Ultrasound O bstet Gynecol $2006 \mathrm{M}$ ar;27(3):286-289.

35. Allan L, Hornberger L. Textbook of fetal cardiology. 1st ed. L ondon, UK : Greenwich M edical M edia; 2000.

36. Bronshtein M, Zimmer EZ. Transvaginal sonography of the normal and abnormal fetus. 1st ed. CRC Press; 2001.

37. Paladini D, Calabrò R, Palmieri S, D'A ndrea T. Prenatal diagnosis of congenital heart disease and fetal karyotyping. Obstet Gynecol 1993 M ay;81[5 (Pt 1)]:679-682.

38. Chaoui R, Heling KS, Sarioglu N, Schwabe M, Dankof A, Bollmann R. A berrant right subclavian artery as a new cardiac sign in second- and third-trimester fetuses with D ow $n$ syndrome. A m J Obstet Gynecol 2005 Jan;192(1):257-263.

39. Zalel $Y, A$ chiron $R, Y$ agel $S$, K ivilevitch $Z$. Fetal aberrant right subclavian artery in normal and Down syndrome fetuses Ultrasound Obstet Gynecol 2008 Jan;31(1):25-29.

40. A chiron R, Gindes L, Gilboa $Y$, Weissmann-B renner $A$, Berkenstadt M. U mbilical vein anomaly in fetuses with Down syndrome. U Itrasound Obstet G ynecol $2010 \mathrm{M}$ ar;35(3):297-301.

41. Smith-Bindman R, Hosmer W, Feldstein VA, Deeks JJ, Goldberg JD. Second-trimester ul trasound to detect fetuses with Down syndrome: a meta-analysis. J A M A 2001 F eb 28;285(8): 1044-1045.

\section{ABOUT THE AUTHOR}

\section{Yaron Zalel}

Professor, Department of Obstetrics and Gynecology, Sheba M edical Center, Tel-Hashomer, A ffiliated to the Sackler School of M edicine Tel-A viv U niversity, Israel

Correspondence Address: 43 Gilad St, Rosh-Haain, I srael 40800 e-mail: zalel1954@gmail.com 